Електронне наукове фахове видання "Ефективна економіка" включено до переліку наукових фахових видань України з питань економіки

(Наказ Міністерства освіти і науки України від 11.07.2019 № 975) www. economy.nayka.com. ua | № 11, 2019|28.11.2019 p.

DOI: $\underline{10.32702 / 2307-2105-2019.11 .173}$

УДК: $658: 69.003$

\author{
V. I. Troian
}

Phd student of the Department of Enterprise and Business Administration O.M. Beketov National University of Urban Economy in Kharkiv

ORCID: 0000-0002-2142-2873

\title{
DEFINING THE BRAND OF CONSTRUCTION COMPANIES AND FACTORS THAT INFLUENCE ITS FORMATION AND USE
}

\author{
В. І. Троян, \\ аспірантка кафедри «Підприємництва та бізнес-адміністрування» \\ Харківського національного університету міського господарства імені О.М. Бекетова

\section{ВИЗНАЧЕННЯ БРЕНДУ БУДІВЕЛЬНИХ ПІДПРИЕМСТВ ТА ФАКТОРИ, ЩО ВПЛИВАЮТЬ НА ЙОГО ФОРМУВАННЯ ТА ВИКОРИСТАННЯ}

The current conditions of operation of domestic enterprises are determined by the eclecticism and insignificance of forms of management, which combine the emergence of new elements, characteristic market conditions, and the preservation of former elements. In full, this concerns the functioning of the construction sector. Its development is accompanied by the formation of economic relations, which at the same time bear the rudiments that determine the functioning of a hierarchically organized system, where there are no partnerships between public authorities and economic entities. They exacerbate the ambiguity of the processes taking place in construction, the lack of "transparency" in the allocation of land for construction, the manifestation of raider hobbies, the opacity of interaction with customers. In such circumstances, it is of particular importance to use modern tools to ensure the investment attractiveness of construction companies by forming and using a brand.

The role of the brand in today's market conditions is increasing, which is associated with fierce competition on the one hand, as well as globalization of economic space, structures, processes and phenomena on the other. Such conditions require a deep understanding of the concept of a brand that is evolving, transforming and becoming more complex. Identifying the factors that influence the formation and use of a brand will help formulate the concept of "brand".

In recent years, there has been an increase in the value of the brand of a construction company, but the level and features of its use indicate a decrease in the efficiency of its formation and use. The brand influences the interaction with customers of construction products, but does not provide a high level of relationships with different groups of stakeholders.

The article is about identifying the factors that influence the formation and use of a brand. The existing theoretical and methodological approaches to defining the brand of construction enterprises are investigated. Analyzes interdisciplinary terminology that influences the formation of brand definition, creates a holistic vision of the concept of "brand". 
Сучасні умови функціонування вітчизняних підприємств визначаються еклектичністю та неодзначністю форм господарювання, щуо поєднують у собі виникнення нових елементів, характерним ринковим умовам, і збереженням колишніх елементів. Повною мірою це стосується функиіонуванням будівельної сфери. Ï̈ розвиток супроводжується формуванням економічних відносин, які в той же час несуть у собі рудименти, що визначають функиіонування ієрархічно організованої системи, де відсутні партнерські відносини між державними органами та суб'єктами господарювання. Поглиблюють неоднозначність прочесів, що відбуваються у будівництві, відсутність “прозорості" при розподілі земель для будівниитва, прояви рейдерських захоплень, непрозорість взаємодії із замовниками. У таких умовах особливого значення набуває застосуванням сучасних інструментів забезпечення інвестииійної привабливості будівельних підприємств шляхом формування та використання бренду.

Роль бренду в сучасних ринкових умовах посилюється, щчо пов'язано з гострою конкуренцією з одного боку, а також глобалізацією економічного простору, структур, процесів та явищ з іншого. Такі умови вимагають глибокого розуміння поняття бренду, яке еволючіонує, трансформується та ускладнюється. Визначення факторів, щуо впливають на формування та використання бренду допоможе сформулювати поняття «бренд».

За останні роки спостерігається зростання значення бренду будівельного підприємства, проте рівень та особливості його застосування свідчить про зниження ефективності його формування й використання. Бренд впливає на взаємодію із замовниками будівельной продукиіі, проте не забезпечується високий рівень взаємовідносин із різними групами стейкхолдерів.

Стаття присвячена визначенню факторів, щуо впливають на формування та використання бренду. Досліджується існуючи теоретико-методичні підходи до визначення бренду будівельних підприємств. Аналізується міжсисииплінарна термінологія, щуо впливає на формування визначення бренду, створюється иілісне бачення поняття «бренд».

Keywords: brand, branding, factors, stakeholders, construction companies.

Ключові слова: бренд, брендинг, фактори, стейкхолдери, будівельні підприємства.

Introduction. Current business conditions require a rethinking of approaches to defining the brand of construction enterprises and the factors that influence its formation and use. In recent years, the functioning and development of construction companies have been determined by the ambiguity and decline in production and economic potential. These processes are influenced by external and internal factors, which largely contribute to certain imbalances and imbalances. In such circumstances, the importance of the brand of construction enterprises and the factors influencing its formation and use increases.

The purpose of the study is to identify the brand of construction companies and the factors that influence its formation and use.

To achieve this goal, the following tasks are solved:

- Substantiation of existing theoretical and methodological approaches to defining the brand of construction enterprises.

- Suggest the author's definition of the brand of construction companies.

- Identify factors that affect branding and branding.

An overview of the latest sources of research and publications.

Significant contribution to the development of theoretical and methodological provisions on brand definition, its formation and use have been made by: D. Aaker, E. Golubkov, K. Keller, O. Kendyukhov, F. Kotler, F. J. LePlais, K. Mamonov, J. Rendell, V. Tamberg, M. Haig and others.

Presenting main material

The research generalizes theoretical propositions and approaches to defining the brand, taking into account the directions of the construction industry. In particular, a symbolic approach (D. Aaker, F. Kotler, M. Haig) is defined, in which a brand is defined as a symbol whose purpose is to identify the goods and services of one manufacturer from its competitors, the manufacturer or producer group, or distinguish it from services or third-party 
products created by a product company endowed with the unique personality that would most clearly set it apart from its competitors. The advantage of this approach is that it allows you to identify the characteristics that identify a brand among different groups of stakeholders. However, there are downsides - it is limited in nature because it ignores other important brand features [3].

Value approach (K. Keller, L. Chernatoni): A brand is characterized as a set of unique and positive associations that arise in the minds of consumers that add acceptable value to a product or service, an identified product, service, personality or place created in such a way that the consumer or buyer perceives the unique added value that best suits his needs. The positive side of the approach is that it provides an opportunity to generate value attributes of the brand, which creates the basis for ensuring its effective use. The disadvantages of this approach are the complexity of evaluating some of the elements in determining brand value.

Consumer Approach (Dallessandro, F. David, R. Sadriev, D. Ogul, M. McDonald, K. Mamonov): focuses on engaging with consumers and identifying consumer brand preferences, characterized as more than advertising or marketing is all that comes to mind about a product when they see its logo or hear the name. The brand identifies positions of lasting impression, holistic image that arises in the mind of the target audience at every contact with the trademark (own name), sign means related to that trademark (own name) and promotes the most complete achievement of the goals facing the trademark owner (own name). As part of the approach, the directions of creating the sum of the properties of a product are formed: its name, packaging and price, its history, reputation and method of advertising, which is a combination of the impression that it makes on the consumer [2].

Functional and emotional values of the brand are used to achieve consumer benefits through which it can convey an attractive and unique promise to its target audiences.

It is determined that the brand is aimed at providing the highest level of consumer perception of the product, its positive associations, or impressions, competitive advantages, which have a long-term character, oriented to the development of the company, consisting of subject, reputation, emotional characteristics [2].

The following characteristics are defined:

subject matter - as a symbol, name, logo, trademark and other visual elements that differentiate a company or product from other similar companies or products;

reputation - as image, reputation, characterizing the uniqueness of the brand and determining the place of the company or product in the market;

qualitative - as a set of impressions, images or feelings that the consumer experiences when purchasing a product with the appropriate brand;

quantitative - as a set of quantitative characteristics that are determined by the term of brand formation, the number of potential buyers of branded goods, the target audience associated with the brand, the number of buyers who use the product with the corresponding brand, the amount of funds that consumers are willing to pay for the branded product;

functional - as a set of features or actions aimed at ensuring the realization of companies' capabilities to achieve competitive advantages and to ensure the growth of sales of goods and cash flows due to the sale of branded goods;

value - as the added value or future added value that the consumer is ready to pay for the branded product;

value - as a set of symbolic, unitary values or long-term assets aimed at meeting the economic, psychological, social and other needs of consumers. The application of the consumer approach allows us to shape the direction of consumer benefits of the branded product compared to others, determined by the tool that brings to consumers a whole combination of benefits, which for the sake of simplicity of presentation and description can be classified as solutions that satisfy the rational and emotional needs of customers. Its functional and emotional values are used to reach the presented positions, thanks to which the brand can convey to its target audiences an attractive and unique promise [2].

The disadvantage of this approach is: low level of information support for assessing the directions of formation of consumer benefits of a brand product, the complexity of determining the functional and emotional values of the brand. Approach based on the level of brand perception (A. Badin, M. Kupchinskaya, Y. Nestereva, M. Newmeyer, V. Orlov, Y. Prikhodchenko, J. Rendell, V. Tamberg): characterizes the brand from the point of view of the person it does not buy goods or services, it only purchases solutions to its problems. And only this problem determines the market product itself, the brand, and its advertising. As part of the approach, a paradigm is formed that each of the products must solve a unique problem or solve a known problem, but in a unique way. Brands are not "soul brands", they are simply stereotypes that the consumer has.

Stereotypes that make it easy to choose are those that contain the benefits that people will get from buying. Intuitive directions of brand perception through the formation of one's own personality are defined, brand is defined as a set of associations of consumers, business partners, contact audiences and staff with the real existing enterprise and its goods, which are determined by its values and distinguished among the competing enterprises. The benefits of the approach include the fact that brand preferences are generated through positive brand perception across different stakeholder groups. The disadvantages of the approach are: it is unclear how to evaluate the benefits of the brand by considering stereotypical thinking, reducing the quality of management decisions [2].

Characteristic approach (P. Bush and M. J. Houston, V. Vlasova, S. Garkavenko, J. Gregory, K. Keller, D. Knapp, F. J. LePla, L. Parker, E. Popov, J. Rendell , E. Sredina, N. Tesakov, P. Feldwick): focuses on important brand characteristics and attributes. The amount of information that buyers have received about a brand is formed 
based on personal experience, advertising, packaging, other people's reviews, and more. And all this information is transformed under the influence of perception, own beliefs, social norms. Brand identity is what the company supplies itself to the market, something that is under its control. Emotional, psychological, and associative characteristics that shape the brand's attitude to different stakeholder groups are highlighted. Allows you to distinguish the characteristics and attributes of the brand, which creates advantages over other brands. The disadvantages of the approach are the complexity of identifying important characteristics and brand features [2].

Management approach (M. Mazuryk, K. Matsler, S. Grabner, Crater, S. Bidmon, N. Ivashova, M. Zhukova, I. Ryabov, G. Studinska, O. Farat): directions of brand creation and use in the system are formed enterprise management. Branding is defined as the art of building and promoting brands in order to shape long-term preferences in society. The main purpose of this process is to strengthen the relationship between the brand and the consumer. Consumers prefer the brand when the brand message is objective and its values are clearly positioned. Allows you to form a trust relationship, whereby consumers enjoy the use of the goods of this brand, determine the principles of brand management. The approach identified the necessity and complexity of forming brand management tools [2].

An approach in which a brand is characterized as an intangible asset (L. Balabanova, O. Rindin, A. Repiev): a brand is defined as an item of intangible assets that is valued by consumers; social psychology category; the insignificant amount of attributes of a product by which consumers have positive associations and distinguish it from competitors, namely the product, its name, symbol, manufacturer, characteristics, packaging, benefits, implies the presence of corporate culture. Defines the ability to display the brand in the existing accounting system. The complexity of defining attributes and associations to form and evaluate a brand has been established.

Classification approach (S. Budko, L. Didkovskaya, A. Fedorchenko, I. Yaroshenko, M. Yanenko): focus attention on brand classification characteristics and divide it into groups:

by brand distribution;

by assortment to which the brand belongs;

by directions and features of brand usage;

by level and market share related to brand products;

the level of use of branding and branding tools;

by the level of influence on the consumer.

Allow to form the basis for management decisions. A decrease in the level of information support in some of the presented classification groups was revealed.

Functional approach (A. Bontur, Zh. Leiko, M. Vasilyeva, A. Nadein, A. Dlyhach, N. Pisarenko, V. Domnin, I. Melnyk, V. Percius, L. Mamleeva, Laura and El Rice, A. Badysh , A. Tulembaeva, G. Schultz): directions and possibilities of brand application are determined [2].

distinguish the following brand features:

a differentiating function of the brand, which is responsible for the ability to separate it from its analogues, to stand out in some way among competitors, to rise above the total number of analogues due to certain advantages or to emphasize its uniqueness;

brand value function: to find, create, add value to the object and ensure its receipt by the consumer;

the protective function of the brand, which protects the investments in the brand, guarantees the originality of origin to the consumer, which will be perceived through certain stable associations;

brand information function that gives the consumer the necessary information (influencing the formation of communication between them) about the object and is implemented through all existing information channels: audio (radio), video (television, video boards), print media (magazines, advertising leaflets etc.), the Internet that most manufacturers are betting on today;

the strategic function of the brand, which is linked to the brand management strategy and its development strategy, as well as the need to evaluate the factors influencing the brand and to determine the additional value that these factors bring to the brand [2].

The laws of brand formation and use are defined:

distribution: brand power is reversed in its use;

judgment: the narrower the scope, the stronger the brand;

public opinion: it is not the advertising but the brand that creates the public opinion;

Advertising: Appeared to the world, the brand, to survive the necessary advertising;

words: the brand must be remembered by the consumer;

credentials: the authenticity of any brand is important to success;

quality: quality is very important, but it is not the one that creates the real brand;

categories: a brand that is a leader should move the category forward, not itself;

name: in the end, the brand is just a name;

lengths: The best way to break a brand is to expand it to infinity;

Communities: To create a category, a brand must collaborate with similar brands;

kind: the best way to destroy a brand is to give it a generic name;

companies: brand is brand, company is company, there is a clear difference between them;

sub-brands: sub-brand destroys what is created by branding;

teammates: need to know when and where to launch a second brand; 
forms: the brand logo should be easy to see with the eye;

colors: the brand needs a color opposite to that of the main competitor;

borders: brand has no borders;

decades;

persistence: it is not possible to create a brand in one night, success comes not even in years, but in

change: brands can change, but in exceptional cases, and very carefully;

natural output: not one of the brands exists forever, sometimes you have to leave the market;

uniqueness: the important quality of a brand is its identity [2].

Particular attention is focused on the areas of engagement with consumers when forming with consumers by offering a specific promise (trade contract), which helps to create a unique image in the mind of the consumer associated with additional values.

The following important functional characteristics of the brand are defined:

the need to take into account the external characteristics of the brand, which must ensure the competitiveness of the brand;

specific characteristics that characterize differences from other brands that are in the same product and price categories;

focusing the brand on the relationship with the consumer, which ensure a stable image in his mind;

branding is for the consumer to see, remember, learn to distinguish and understand the meaning;

directions that symbolize important aspects of the consumer's life;

the brand is physically accessible to $75 \%$ of potential buyers from the target audience;

$75 \%$ of the target audience can accurately describe the brand's business by brand name;

at least $20 \%$ of target audience buyers use it regularly;

at least $20 \%$ of buyers from the target audience can correctly identify the main brand descriptors;

has been on the market for at least 5 years;

buyers are willing to pay a price that exceeds the average price for similar products in the category. The advantage of the approach is that it defines the functional characteristics and characteristics that allow to provide directions of brand use in the enterprise management system. The disadvantage of the approach - focusing on specific features and characteristics leads to a decrease in the completeness of the definition of the brand and the ability to make sound management decisions [2].

Value approach (K. Bovet and U. Arens, K. Buksha, L. Wood): aimed at defining a brand through the prism of cost characteristics, is considered as a long-term asset that forms the added value of the product. It connects value and brand, determines that brands can assign one or the other value, then abandon it and use any other value. The brand stands out: name, slogan, packaging, logo, corporate identity, brand image, way of interaction with the outside world. The total value of a brand, shaping its value, distinguishes functional, emotional and self-expressive components. Allows you to form a quantitative basis, in value form, to make effective management decisions, to introduce a diagnostic and monitoring system of brand assessment, to systematically investigate changes in its formation and use. As part of the approach, there are problems with the completeness and quality of the information used to evaluate some of the indicators that shape brand value [2].

The combined approach (E. Golubkov, O. Kendyukhov, S. Dimitrova, L. Radkevich, O. Kuzhilev, I. Reshetnikov): is determined by the set of features and characteristics, the provisions presented in the previous approaches. The brand is defined as a trademark;

synonymous with a trademark, sometimes a trademark;

symbol of added value;

a generic view of the product, the sum of all the mental connections that are created between buyers and the product of that brand;

prestigious, popular, well-known trademark. The following characteristics are distinguished: the properties of the product, its name, packaging, price, history, reputation, advertising tools that reflect the symbiosis of the impressions that the brand has on consumers.

A system consisting of qualitative, quantitative, physical, emotional and intellectual traits is formed. The formation and use of the brand is influenced by external positioning, internal culture, company mission, high level of intellectual capital, external marketing concept, corporate development concept.

The set of functional, emotional and expressive promises to the target buyer are distinguished. As part of the approach, the brand building process is a set of activities aimed at creating it and a value is formed, which consists of total values and total costs. Allows you to identify the various features, characteristics and provisions that define the brand as a system category that affects the functioning of businesses. There are certain problems in reducing the level of information and analytical support, due to the complexity of obtaining information on some characteristics and characteristics, the identification of the brand with the brand leads to a decrease in the ability to determine its uniqueness and management [2].

Therefore, taking into account the presented theoretical and methodological approaches, the concept of a construction company brand is proposed, which is defined as a long-term asset, which is formed from a set of system symbols and functional, emotional, visual characteristics that create stakeholder unique and positive associations that provide corporate advantages the added value of construction products to increase the investment attractiveness of a construction company. 
On the basis of generalization of theoretical and methodological approaches, regulatory and legal factors are determined factors of formation and use of the brand of construction enterprise: emotional, consumer value of the brand, stakeholder relations, changes in the value of the brand of construction products, its strength, corporate culture and security, the level of financial status. The factors of formation and use of a construction company brand provide a quantitative basis for its evaluation. The proposed factors form the information and analytical support of the assessment, which is the basic system element for determining the relevant indicators and building a diagnostic system for creating and using a brand of a construction company. This made it possible to create a systematic environment for creating organizational and economic foundations for the development and use of the construction enterprises brand and provided opportunities for the use of modern tools for increasing the investment attractiveness of construction enterprises and making sound management decisions [2].

\section{Conclusions.}

Thus, the definition of the concept "brand of construction enterprises" is offered, a distinctive feature of which is the consideration of system symbols and functional, emotional, visual characteristics, which create unique and positive associations for the stakeholders, which allows to secure the growth of investment attractiveness, to apply the modern economic management tool, to form a quantitative basis for making sound management decisions;

The substantiated factors of formation and use of the brand of construction enterprises on the basis of basic emotional, consumer, stakeholder, value, corporate, security, financial characteristics, which unlike the existing ones, allows to develop and implement an approach to the integral evaluation of the brand and to develop its organizational and economic form using.

\section{References.}

1. Aaker, D. (1996), Building Strong Brands, Free Press, New York, USA.

2. Keller, K. (2002), Branding and Brand Equity, Marketing Science Institute, Cambridge, Massachusetts.

3. Mamonov, K. A. (2012), "Stakeholder strategy of value-oriented capital management of brand of construction enterprises", Abstract of Ph.D. dissertation, Economics and Management of Enterprises (Construction Economics), O.M. Beketov National University of Urban Economy in Kharkiv, Kharkiv, Ukraine.

4. Studinska, G. Ye. (2014), "Methodological approaches to the definition of the concept of "brand", Naukovyj vistnyk Khersons'koho derzhavnoho universytetu, vol. 8, pp. 121-125.

5. Dligach, A. P. (2007), "Marketing research in the development of brand strategies", Marketynhovye yssledovanyia v Ukrayne, vol. 2, pp. 24-31.

6. Wilson, R.M. (1998), Strategic Marketing Management, Buttcrworth-Heinemann Ltd, Oxford, UK.

Стаття надійшла до редакиіï 07.11.2019 р. 